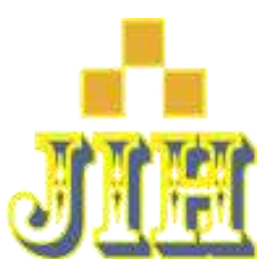

\title{
Politisasi Isu Agama di Media Massa: Strategi Politik Hos Cokroaminoto dalam Surat Kabar Djawi Hisworo (1918)
}

\author{
Ahmad Fajar, \\ IAIN Salatiga \\ fjrahmad46@gmail.com
}

\begin{tabular}{|c|c|c|}
\hline Submited: & Revision Required: & Published: \\
13 April 2021 & 19 Mei 2021 & 15 Juni 2021 \\
\hline
\end{tabular}

\begin{abstract}
Hos Cokroaminoto is a politician as well as the leader of Sarekat Islam movement at the beginning of the $20^{\text {th }}$ century. He was an active figure in the early world of the movement in the Hindia Belanda. In its political activity in 1918, he politicized the polemic of blasphemy in the newspapers of Djawi Hisworo to strengthen his political standing and attack his enemies. Through this politicization, Cokrominoto managed to attract many followers and mobilize the masses consisting of muslim. In this study, the author uses historical research methods wich include soirce criticism, interpretation, and historical writing.This writing is written with analitycal descriptive type. Research resource, among others: (1) Cokroam inoto politicized by attracting modernist Muslims to revive the branches of Sarekat Islam wich at the time were neglecte. (2) He also succeeded in estabilishing the Tentara Kandjeng Nabi Muhammad for the media movement. (3) He also managed to raise funds from Muslim merchants so many. Cokroaminoto then expelled enemies in the Communist-leaning Sarekat Islam which at the time became an obstacle for him to carry out his political activities.
\end{abstract}


Keywords: cokroaminoto, djawi hisworo, politization

\section{ABSTRAK}

HOS Cokroaminoto merupakan seorang politikus sekaligus pemimpin pergerakan Sarekat Islam pada awal abad ke 20. la merupakan seorang tokoh yang aktif dalam awal dunia pergerakan di Hindia Belanda. Dalam aktifitas politiknya pada tahun 1918, ia melakukan politisasi terhadap polemik penistaan agama dalam surat kabar Djawi Hisworo untuk memperkuat kedudukan politiknya dan menyerang musuh-musuhnya. Melalui politisasi tersebut, Cokroaminoto berhasil menggaet banyak pengikut dan memobilisasi massa yang terdiri dari umat Islam. Dalam penelitian ini, penulis menggunakan pendekatan metode penelitian sejarah yang meliputi pengumpulan data, kritik sumber, penafsiran, dan penulisan sejarah. Penulis juga menggunakan pendekatan biografi. Penulisan ini ditulis dengan jenis deskriptifAnalitis. Hasil penelitian antara lain: (1) Cokroaminoto melakukan politisasi dengan menggaet umat Islam modernis untuk membangkitkan kembali cabang-cabang Sarekat Islam yang pada saat itu terbengkalai. (2) Beliau juga mendirikan Tentara Kandjeng Nabi Muhammad untuk media pergerakan. (3) la juga berhasil mengumpulkan dana dari saudagar-saudagar muslim dengan begitu banyak.. (4) Cokroaminoto kemudian mendepak musuh-musuhnya dalam Sarekat Islam yang berhaluan Komunis yang pada masa itu menjadi penghalang bagi dirinya untuk melancarkan kegiatan politiknya.

Kata Kunci: cokroaminoto, djawi hisworo, politisasi

\section{PENDAHULUAN}

Persoalan politik sering menjadi pembahasan yang menarik. Manusia selalu berkaitn dengan politik kapanpun dimanapun. Politik seringkali berkaitan dengan agama, seperti politisasi agama. Di Hindia Belanda, politisasi agama sudah terjadi pada awal abad ke-20. Pada masa ini adalah masa awal pergerakan kemerdekaan Indonesia. Politisasi dilakukan oleh Hadji Oemar Said Cokroaminoto yang merupakan pahlawan nasional, tokoh pembaharu Islam, sekaligus guru bapak pendiri bangsa Indonesia. Cokroaminoto melakukan politisasi terhadap polemic penistaan agama pada surat kabar Djawi Hiswara yang pada 
tahun 1918 melakukan penistaan terhadap agama Islam melalui artikel yang diterbitkan.

Politisasi secara bahasa berarti hal yang membuat suatu keadaan berifat politis. Atau, menjadikan hal suatu hal bersangkutan dengan politik. Sepintas, tak ada konotasi negatif dari makna politisasi. Bahkan, politisasi bisa dianggap sebagai bagian dari proses politik. Politisasi sering digunakan untuk menggambarkan cara-cara berpolitik yang tidak etis dan pragmatis. Dan, seolah ada kesepakatan umum, termasuk para politisi, memusuhi politisasi. Padahal, tidak semua politisi terlepas dari politisasi (Ahmad Sadzali, 2018). Dalam peristiwa politik, terdapat politisasi yang berkaitan dengan agama. Jika politisasi dikaitkan dengan agama, maka hal ini disebut politisasi agama. Politisasi agama merupakan suatu perbuatan yang berupa gagasan, ide, pemahaman dan lain sebagainya yang berkenaan tentang keagamaan menjadi bersifat politik. Dengan kata lain, dalam politisasi agama, terdapat instrumentalisasi agama untuk kepentingan politik tertentu. Politisasi agama juga menjadi salah satu konsep penting dalam memahami Teologi Politik seperti Islam Politik, dimana agama memiliki daya fungsional strategis terhadap realitas politik yang ada (Budi Kurniawan, 2018).

Polemik merupakan suatu perdebatan mengenai suatu masalah yang dikemukakan secara terbuka dalam media massa. Polemik mengenai isu agama merupakan suatu hal yang sering terjadi dalam kontestasi politik. Isu agama dapatmenjadi sebuah pembahasan yang dapat dilakukan oleh para politisi dalam aktivitas politiknya. Agama sendiri merupakan suatu bahan yang paling mutakhir untuk mencari pundi demi pundi guna menaikkan elektabilitas politik. Isu agama adalah isu yang hangat dan sangat mudah dipermainkan dalam permainan politik. Agama dan politik tidak bisa lepas dari kehidupan manusia (Muhammad Luthfi Afd hal, 2019).

Penistaan agama merupakan suatu tindakan pelecehan, penodaan, dan hujatan terhadap suatu ajaran, kebudayaan, dan keyakinan suatu agama yang dilakukan melalui ucapan, tulisan maupun perbuatan. Penistaan agama Islam sudah dilakukan pada zaman rosulullah dan semenjak turunnya Al-Quran. Penistaan dilakukan secara sengaja maupun tidak sengaja untuk melukai dalam bentuk provokasi yang dilakukan baik oleh individu maupun kelompok 
kepada individu atau kelompok yang lainnya yang mengakibatkan penganut agama atau keyakinannya tersinggung.

\section{PEMBAHASAN}

\section{Konfigurasi Politik Sarekat Islam Dibawah Cokroaminoto}

Hadji Oemar Said Cokroaminoto merupakan seorang ulama, pedagang, politikus, dan pahlawan Nasional. la merupakan seorang tokoh yang memperjuangkan status bumiputra untuk mendapatkan kedudukan setara dengan orang-orang asing. la sangat disegani oleh banyak orang, terutama dari golongan Nasionalis Islam. ${ }^{1}$ Cokroaminoto mengawali karir politiknya dalam Sarekat Islam. ${ }^{2}$ Cokroam inoto mulai diperkenalkan dengan Sarekat Islam ketika dibukanya cabang Sarekat Islam di Surabaya. melalui kecerdasan dan ketertarikannya terhadap Sarekat Islam, pada akhirnya ia diangkat menjadi ketua cabang Sarekat Islam di Surabaya. Ditangan Cokroaminoto Sarekat Islam menjadi organisasi yang dapat memobilisasi massa, bahkan ia mengadakan Vergadeering ${ }^{3}$ (rapat terbuka) besar pada 26 Januari 1913 di Surabaya. Cokroaminoto yang menjabat sebagai ketua SI Surabaya juga mengumumkan bahwa jumlah anggota SI pada masa itu sudah mencapai 80.000 anggota. Dibawah Cokroaminoto Sarekat Islam mengalami puncak kejayaannya pada tahun 1912-1918. ${ }^{4}$

${ }^{1}$ Raden Mas Oemar Said Cokroaminoto lahir di Bakur, Sebuah desa sunyi pada tanggal 16 Agustus 1882 bertepatan dengan tahun meletusnya gunung Krakatau di Banten. Peristiwa ini sering dikiaskan oleh orang Jawa bahwa gunung meletus itu akan banyak menimbulkan perubahan terhadap alam disekelilingnya. Peristiwa ini pula yang kelak dikaitkan dengan meledaknya tuntutan HOS Cokroaminoto terhadap Pemerintah Kolonial Belanda ketika ia menjadi pemimpin Sarekat Islam. la terlahir dengan nama Oemar Said. Namun setelah ia menunaikan ibadah Haji ia kemudian memperkenalkan diri dengan nama Haji Oemar Said Cokroaminoto, atau lebih dikenal dengan HOS Cokroaminoto (Amelz, 1952).

2 Sarekat Islam adalah sebuah organisasi dagang yang didirikan oleh Haji Samanhoedi pada 26 Oktober 1905. Pada awalnya organisasi ini bernama Sarekat Dagang Islam. Organisasi ini didirikan untuk menggalang kerjasama antara pedagang Islam untuk kesejahteraan pedagang Islam pribumi, serta untuk melawan dominasi perdagangan dari orang-orang Thionghoa. Namun pada tahun 1912 Cokroaminoto menggantinya dengan nama Sarekat Islam (Sarekat Islam: Pendirian, Perkembangan, dan Perpecahan, Kompas.com 21/12/2020).

3 Vergadeering, Rapat terbuka.

${ }^{4}$ Dilaporkan jumlah dari cabang-cabang yang hadir dan jumlah anggota yang sudah bergabung, Semarang (1.027 anggota), Kudus (2.033 anggota), Malang (457 
Momen bersejarah bagi Cokroaminoto terjadi pada tahun 1914 pada saat kongres di Yogyakarta. Cokroam inoto ditunjuk untuk menjadi ketua Sarekat Islam, menggantikan Samanhoedi. ${ }^{5}$ Kepiawaian Cokroaminoto membuat ia lebih disegani dan dihormati oleh anggota lainnya. la lebih berhasil menarik banyak pengikut dari pada Samanhoedi. SI Surabaya berada dibawah kendalinya dan ia berhasil menjadi direktur Setia Oesaha menggantikan Hasan Ali Soerati. Untuk memantapkan posisinya, ia membagikan jabatan-jabatan dalam SI kepada orang-orangnya. la juga membuka cabang-cabang SI diberbagai daerah terutama Jawa Tengah dan Jawa Timur. la mengubah haluan SI yang pada awalnya hanyalah organisasi yang bergerak dalam bidang ekonomi menjadi sebuah organisasi yang bergerak dalam bidang Sosial, Ekonomi, dan Politik.

Dalam pergerakanya, Cokroaminoto mengambil sikap kooperatif dengan pemerintah Hindia Belanda. Cokroaminoto meminta para anggotanya untuk bersikap baik dan tidak menunjukkan sikap perlawanan kepada pemerintah Hindia Belanda. Hal ini bertujuan supaya SI mendapatkan status hukum yang jelas. Cokroaminoto berupaya untuk memperoleh Status Badan Hukum guna mendapat pengakuan yang sah dari pemerintah Hindia Belanda demi melancarkan pergerakan-pergerakan SI. ${ }^{6}$ Menjelang akhir tahun 1913 Cokroaminoto terus melakukan perjalanan ke pelosok-pelosok daerah guna mengunjungi cabang-cabang seperti Kediri, Blitar, Bondowoso, Jember, Banjarnegara, Pekalonggan, dan Pati. Pada kunjungannya

anggota), Sepanjang (258 anggota), Madiun, Ngawi, Ponorogo, Jombang (1.060 anggota), Parakan (3.769 anggota), Solo (6400 anggota), Bangil (164 anggota), Sidoarjo (217 anggota), Surabaya (6.000 anggota). Baca Tim Museum Kebangkitan Nasional, Djoko Marihandono, Harto Juwono, Yudha B Tangkilisan, HOS Cokroaminoto Penyemai Pergerakan Kebangsaan dan Kemerdekaan, (Museum Kebangkitan Nasional Kementrian Pendidikan dan Kebudayaan). HIm. 8

5 Kongres ini dihadiri oleh 147 delegasi yang mewakili 440.000 anggota. Sebagai apresiasi terhadap jasa-jasa Samanhoedi, hasan djajaningrat kemudian mengusulkan diangkatnya Samanhoedi sebagai Ketua Kehormatan. Para anggota SI menunjuk Cokroaminoto dan meminta Samanhoedi untuk menyerahkan jabatan ketua kepada generasi muda yang lebih kompeten. Ibid, . hal 59-61.

${ }^{6}$ Pada masa itu, sebuah organisasi yang tidak memiliki status badan hukum dapat dibubarkan setiap saatoleh Residen, berdasarkan undang-undang 1854 (Pasal III). 
tersebut, ia bersama dengan Dr. Rinkes. ${ }^{7}$ Atas kesuksesannya dalam mengem bangkan Sarekat Islam, pada kongres di Yogyakarta pada 1920 April tahun 1914, Cokroaminoto dipilih menjadi ketua Central Sarekat Islam. la berhasil menggantikan Samanhoedi dan memindahkan pusat kegiatan Sarekat Islam dari Surakarta ke Surabaya. Sedangkan, samanhoedi diberi gelar "Ketua Kehormatan", yang merupakan suatu gelar yang tidak memiliki wewenang apapun. Kongres tersebut dihadiri oleh 147 delegasi, mewakili 81 cabang SI dari berbagai daerah yang terdiri dari 440.000 anggota. Dalam rencananya menggantikan Samanhoedi ia dibantu oleh Dr Rinkes. ${ }^{8}$

Semenjak Cokroaminoto terpilih menjadi Ketua Central Sareka Islam (CSI), Samanhoedi tidak memiliki wewenang apapun termasuk dalam hal keuangan yang pada saat itu sedang mengalami kenaikan. la merasa dirugikan karena sebernanya ialah pendiri SI dan berusaha untuk mendapatkan kembali kedudukan kekuasaan dalam tubuh SI. la kemudian bekerja sama dengan Raden Gunawan dan mendirikan SI Pusat Batavia yang kemudian menjadi oposisi Cokroaminoto di Surabaya, dengan mencari dukungan cabang-cabang SI Jawa Barat dan Sumatra. Meskipun cabang SI kebanyakan mengikuti Cokroaminoto, namun terjadi perpecahan dalam tubuh SI antara kubu

7 Dr Rinkes merupakan penasihat urusan bumiputera yang ditugaskan membimbing Sarekat Islam dijalan yang dipilih pemerintah, menggantikan Dr Hazeu. la membantu dalam penyusunan anggaran dasar Sarekat Islam dan pembukaan cabang Sarekat Islam Lokal. Cokroaminoto bekerja sama dengannya karena ia memiliki hubungan langsung dengan Gubernur Jendral dan dapat berunding dengan Residen. Kerjasama ini dimanfaatkan dengan baiik oleh Cokroaminoto.Takashi Siraishi, Zaman Bergerak, Radikalisme Rakyat Jawa 1912-1926, (Jakarta : Putaka Utama Grafiti) HIm. 96-98

${ }^{8}$ Dr Rinkes mengatakan berkata dihadapan forum tertinggi SI, "Samanhoedi tidak memiliki semua persyaratan menjadi pemimpin yang baik. la tidak terdidik, menurut Islama maupun ukuran modern, berpikiran sempit mengenai segala hal diliuar lingkungannya, tak punya kemampuan berbicara, keras kepala dan bertindak semaunya ." Kemudian ia melanjutkan, "Sebaliknya, Cokroaminoto memiliki latar belakang yang baik, pikiran yang terbuka dan tidak dibatasi oleh pertimbanganpertimbangan agama. Berpendidikan layak dan berpengetahuan, juga memiliki nalun politik yang layak dalam beberapa hal. (Iswara N Aditya, Taktik Cokro Menggulingkan Prtahana, (Tirto id : Humaniora) 18 Februari 2017.https://tirto.id/taktik-tjokroaminotomenggulingkan-petahana-cjiP) 
Samanhoedi-Gunawan dengan kubu Cokroaminoto-Abdul Moeis. ${ }^{9}$ Meskipun Cokroaminoto sudah menjadi ketua CSI, nam un keberadaan Gunawan tidak bisa dianggap remeh, karena Gunawan juga memiliki banyak pengikut dan memiliki pengaruh yang kuat diwilayah Jawa Barat dan Sumatra. Sementara itu, Cokroaminoto mendapat dukungan dari Soewardi, Abdoel Moeis, Djajaningrat dan anggota-anggota SI Jawa Timur (Tim Museum Kebangkitan Nasional, t.t.).

Gunawan melakukan gebrakan saat kongres di Surabaya tahun 1915. Gunawan membentuk aliansi bersama Samanhoedi dengan mengundang para utusan Sarekat Islam Lokal Sumatra yang tidak mendapat jabatan komisaris ke Surakarta. Gunawan menerbitkan rancangan anggaran dasar "CSI Batavia dan Sumatra" di Pantjaran Warta dan melakukan Vergadeering pertama pada Januari 1916. Hoofdbeestur ${ }^{10}$ dibentuk dengan Samanhoedi sebagai ketua dan Gunawan sebagai sekretaris/bendahara (Tim Museum Kebangkitan Nasional, t.t.). Pergerakan yang dilakukan oleh Samanhoedi dan Gunawan kemudian menimbulkan reaksi dari tubuh SI Pusat. Redaksi Kaoem Muda yang pada saat itu menjadi organ SI Bandung yang diketuai oleh Abdul Moeis memberitahukan bahwa Gunawan telah melakukan suatu tindakan yang tidak sah. Redaktur menerima salinan surat dari Gunawan yang memberitahukan bahwa SI Jawa Barat telah melakukan rapat umum yang dihadiri oleh semua wakil SI Jawa Barat. Abdoel Moeis melakukan serangan-serangan kepada Gunawan dengan alasannya yang tidak memberitahu dan meminta persetujuan Cokroaminoto yang merupakan ketua CSI. Selain itu, jika Gunawan terus menerus merasa dirinya adalah pemimpin SI, maka ia merupakan pemecah belah persatuan SI. ${ }^{11}$

${ }^{9}$ Wido Aditya, Pengaruh Polemik Djawi Hisworo Terhadap Kondisi Sarekat Islam, (Fakultas Sastra dan Seni Rupa, UNS). HIm. 26-27

10 Hoofdbesstur, merupakan kata yang berasal dari bahasa Belanda yang artinya Pengrus Besar.

11 Abdul Moeis juga menanggapi perbuatan Goenawan dan Samanhudi tersebut dengan menulis dalam Kaoem Muda bahwa Gunawan jelas ingin menjadi ketua SI sekaligus menjadi bendahara, agar ia tak perlu menyerahkan uang yang masih berada dalam kas sebesar f 8.000 dan ada banyak uang kepada penguns lokal. Abdul Moeis menganggap itu hanyalah permainan kata-kata, karena pengurus pusat tidak diberitahu. Sedangkan Sinar Djawa yang menjadi organ SI Semarang menuliskan bahwa orang-orang seperti Goenawan yang menjadi pemilik Hotel Samirono secara tidak sah (Dahulu milik N.V Medan Priaji dengan nama Holet Medan 
Untuk melawan kekuatan Goenawan, Cokroaminoto kemudian melakukan berbagai cara dengan memasukkan orang-orangnya ke Jawa Barat untuk mengurangi pengaruh Gunawan. Cokroaminoto melakukan dua hal, yaitu menunjuk Adiwinatadari Batavia sebagai bendahara CSI agar lebih mudah menyedot uang dari SI di berbagai daerah Sumatra. Kemudian Cokroaminoto melakukan tur propaganda ke Palembang dan menghalangi SI Palembang yang makmur untuk bergabung dengan CSI nya Gunawan. COkroaminoto kemudian mendapatkan dukungan dari dua sumber. Pertama, Gunawan diterpa serangan dari Tjipto Mangoenkoesoemo yang mengekspose penyelewengan uang SI oleh Goenawan sebanyak 60.000 gulden, dan menyerangnya sebagai Satria Maling. ${ }^{12}$

Dukungan kedua, datang dari pemerintah Hindia Belanda dengan dberikannya pengakuan hukum bagi CSI Cokroaminoto. Pada akhirnya, usaha Gunawan gagal. Meskipun SI Lokal Batavia, Benkeulen, dan Lampung sudah bergabung ke CSI nya Gunawan. Pada akhirnya mengundurkan diri satu persatu. Cokroaminoto kemudian mengadakan Kongres Nasional CSI pada Juni 1916 di Bandung, dan menunjuk Abdul Moeis yang merupakan orang Sumatra sebagai Ondervoorzitter (Wakil Ketua). Pada akhir tahun 1916 Gunawan menghentikan usaha-usahanya dan dipecat dari SI Batavia. Tantangan Gunawan terhadap Cokroaminoto dengan kekalahannya dengan jelas menunjukkan gerakan SI dibawah Enhoofdbeestur Cokroaminoto. Tantangan Goenawan sepenuhnya berdasarkan perubahan perimbangan kekuatan SI secara geografis karena macetnya SI Jawa dan munculnya SI Sumatra. Sementara itu isu yang diangkat adalah uang dan posisi kekuatan antara Cokroaminoto dan Gunawan (Takashi Siraishi, t.t.: 105-106). Meskipun Cokroaminoto berhasil mengalahkan Goenawan, namun ia tidak bisa memperkuat kedudukannya dan menggaet banyak pengikut. Kepercayaan

Priaji) tidak diharapkan bahwa dia akan menjadi pemimpin dan pengelola kas yang baik.

12 Serangan ini menjadi bencana bagi Goenawan karena selama itu dia dianggap sebagai seorang pemimpin pergerakan oleh pengikutnya. Apalagi serangan ini dilakukan oleh Tjipto yang telah membuktikan pengorbanannya kebada bangsa dalam kasus Comite Boemipoetra (Takashi Siraishi, t.t.: 105-106) 
masyarakat terhadap SI mulai hilang dan SI mulai mengarah pada kekosongan. Pada akhir 1916 pembentukan SI lokal di Sumatra berhenti dan dana dari SI lokal Sumatra yang mengalir ke CSI pun terhenti. Walaupun keanggotaannya terus bertam bah, tetapi tidak ada gagasan baru dari seorang Cokroaminoto yang mampu menggerakkan masyarakat. la tetap menjadi seorang Ksatria dibawah perlindungan pemerintah. ${ }^{13}$

Perpecahan dalam tubuh SI kembali muncul ketika infiltrasi Komunis dalam tubuh SI semakin besar. Masuknya Komunisme dalam tubuh SI menjadi ancaman bagi Cokroaminoto sebagai ketua CSI. Banyak tokoh-tokoh SI yang terpengaruh oleh faham Komunisme terutama dari SI Semarang yang dipimpin oleh Semaoen. ${ }^{14} \mathrm{SI}$ pun kemudian terpecah menjadi dua kubu yaitu SI Merah yang dipimpin oleh Semaoen dan Darsono yang berpusat di Semarang dengan SI Putih yang dipim pin oleh Agus Salim dan Abdoel Moeis di Yogyakarta. Pada awalnya Cokroaminoto menjadi penengah dari dua kubu yang berseberangan tersebut, Namun pada akhirnya Cokroaminoto berpihak pada SI putih.

Pada kongres SI ke dua di Jakarta tahun 1917, Sarekat Islam menegaskan tujuannya yakni kemerdekaan. Namun perumusan tersebut belum dipertegas dan diperjelas karena dikhawatirkan akan membawa dampak pada Sarekat Islam. Pada kongres kedua ini juga disinggung mengenai masalah Volksraad (Dewan Perwakilan Rakyat). ${ }^{15}$ Cokroaminoto dan CSI mendukung adanya Volksraad.

${ }^{13}$ Pada akhir 1916 karir Goenawan dalam Sarekat Islam berakhir. la dipecat dan tidak lagi mendapat kepercayaan dari pendukungnya yang dulu loyal meskipun dugaan penggelapan uang itu tidak jelas tanpa pernah diajukan ke pengadilan. Setelah dipecat, ia pun kembali mengelola surat kabar Pantjaran Warta. la kemudian bergerak bersama Marco dan mendekati SI Semarang. Silahkan baca Iswara N Raditya, Tuduhan Korupsi dan Tamatnya Raden Goenawan dalam Sarekat Islam, (Tirto Id: Humaniora).

14 Semaoen lahir di Mojokerto pada 1899 . Merupakan pribumi pertama yang menjadi propagandis pertama serikat buruh. la bukanlah keturunan Priayi, namun ia mengenyam pendidikan dasar gaya barat. la menjadi sekretaris di SI Afdeling Surabaya pada 1914. Pada 1915 ia bertemu dengan Sneevliet dan menjadi muridnya, kemudian menjadi ketua SI Semarang pada tahun 1917

15 Volksraad diambil dari Bahasa Belanda yang berarti "Dewan Rakyat", Merupakan sebuah Dewan Perwakilan Rakyat Hindia Belanda. Dewan ini dibentuk pada tanggal 16 Desember 1916 oleh Pemerintah Hindia Belanda yang diprakarsai 
Selain SI secara langsung mendapat tempat dalam perpolitikan di Hindia Belanda, Volksraad dapat menjadi dapat menjadi sebuaharena untuk memperjuangkan rakyat Hindia dalam hal pendidikan, kesejahteraan, kedudukan, dan sebagai daya tawar untuk mendapatkan kedaulatan. Pada akhirnya CSI memiliki dua kursi dalam Volksraad yang diduduki oleh Cokroaminoto dan Abdul Moeis. Namun keterlibatan SI dalam Volksraad kemudian menimbulkan perselilihan dalam tubuh SI. Disisi lain, banyak pemimpin-pemimpin SI terutama dari SI Semarang tidak menyutujui keberadaan Volksraad. Seperti Semaoen yang tidak menyutujui jika SI mengirimkan wakilnya dalam Voksraad. Menurut Semaoen, SI dengan dasar politiknya harus menuju pemerintahannya sendiri. Kemunculan Semaoen sangatmengganggu Cokroaminoto. Dibawah kendalinya, SI Semarang berhasil menarik banyak pengikut. la melakukan kritikan kepada Cokroaminoto atas keterlibatannya di Volksraad dan melakukan aksi kampanye menentang Indie Werbaar. ${ }^{16}$ Semaoen terus mengganggu supremasi Cokroaminoto dan menganggap dia adalah "Seorang Ksatria dibawah perlindungan pemerintah" serta menganggapnya tidak berpihak kepada rakyat dan kurang radikal dalam menghadapi penjajahan yang dilakukan oleh Pemerintah Hindia Belanda (Muhammad Subarkah, 2020).

Kegiatan-kegiatan yang dilakukan oleh Semaoen sangat menggangggu aktivitas politik Cokroaminoto. la kemudian sadar, bahwa semangat militant saja tidak mampu untuk mendominasi kekuasaan dalam SI. Pada akhirnya, Cokroaminoto melakukan semangat demokrasi dan gerakan sosial untuk memperkuat kedudukannya. Pertama, ia mendukung gerakan Djawa Dwipa. ${ }^{17}$

oleh GubernurJendral Van Limburg Stirum bersama dengan Mentri Urusan Koloni Belanda ; Thomas Bastiaan Pleyte. id.wikipedia.org/wiki/Volksraad

16 Indie Weerbaar merupakan kelompok pertahanan bersenjara (milisi) bumiputra pada masa Kolonial Belanda. Organisasi dibicarakan pada tahun 1913 dan 1917. Kelompok ini didukung oleh organsiasi seperti Boedi Oetomo dan Sarekat Islam melalui mekanisme sidang di Volksraad

${ }^{17}$ Djawa Dwipa merupakan sebuah gerakan yang bertujuan untuk menghapus Bahasa Jawa tinggi (Kromo) menjadikan Bahasa Jawa rendah (Ngoko) menjadi Bahassa Jawa standar. Gerakan ini mulanya dilakukan oleh Tirtodanodjo dan Tjokrosoedarmo di Surabaya. Mereka juga mengganti gelar priayi dengan gelar Djawa Dwipa. Wiro (lakilaki), Woro (perempuan yang sudah menikah), dan Roro 
Kedua, Cokroaminoto kemudian bertindak seperti dimasa-masa awal yaitu dengan menggunakan daya tarik Islam dengan menghimpun kaum putihan, khususnya saudagar-saudagar Arab. Kesempatanemas didapatkan Cokroaminoto dengan memanfaatkan sebuah artikel yang berisi penistaan agama pada surat kabar Djawi Hisworo.

\section{Penistaan Agama Pada Surat Kabar Djawi Hisworo}

Djawi Hiswara adalah surat kabar yang didirikan di Solo pada tahun 1909 bersama tiga surat kabar yang lainnya. Surat kabar ini merupakan kelanjutan bahasa melayu dari Djawi Kanda. Penyunting Djawi Kanda dan Djawi Hiswara adalah Raden Martodharsono yang sebelumnya merupakan redaktur dari Medan Priaji dari Tirto Adhi Soerjo. Redaktur Djawi Kanda oleh Dirdoatmodjo di Surakarta dan Dr Wahidin di Yogyakarta, surat kabar ini diterbitkan oleh Albert Rusche Co. Pada tahun tersebut, banyak surat kabar yang didirikan didaerah Vorstenlanden. ${ }^{18}$ Djawi Hisworo merupakan koran berbahasa Jawa dan menerbitkan artikel-artikel bahasa Jawa. Surat kabar ini muncul atas kesadaran priayi profesional yang sadar akan kondisi pribumi yang mengalami kemunduran baik dari orang Belanda maupun Tionghoa (Takashi Siraishi, t.t.; 51). Djawi hisworo pada awalnya berkantor di Kampung Mesen, tetapi kemudian pindah ke sebelah selatan loji karesidenan yang sekarang menjadi gedung Kotapraja Surakarta. Selanjutnya, surat kabar ini pindah ke Kampong Loji Wurung yang sekarang menjadi kantor Jawatan Sosial. Surat kabar ini terbit tiga kali seminggu pada Selasa, Rabu, dan Jum'at. Ditangan Martodharsono ${ }^{19}$,

(perempuan yang belum menikah). Para pendukung Djawa Dwipa tidak meninggalkan bahasa kromo untuk mengungkapkan rasa hormat yang begitu mendalam, tetapi mninggalkannya ketika berbicara kepada pegawai. Gerakan ini merupakan sebuah ekspresi khas orang Jawa tentang Demokrasi dan pelan-pelan menjadi popular dikalangan priayi pemerintah yang muda dan orang particeulir.

18 Vorstenlanden adalah daerah-daerah yang berada dibawah kekuasaan empat monarki pecaha dari Kesultanan Mataram, yaitu Yogyakarta, Surakarta, Pakualaman, dan Mangkunegaran. Istilah ini lebih merujuk pada wilayah Yogyakarta dan Surakarta. Mengindikasikan bahwa wilayah tersebut merupakan daerah istimewa yang berhak memerintah dirinya sendiri.

19 Martodharsono merupakan seorang jurnalis di awal abad 20 an. la adalah seorang redaktur dari surat kabar Djawi Hiswara. Martodharsono menjadi orang yang paling dekat dengan Samanhoedi. la dipercaya oleh Samanhoedi dan menjadi tangan kanannya. Pada saat pembentukan SDI (Sareka Dagang Islam),ia ia menjadi perantara Tirto Adhi Soerjo dan Samanhoedi untuk menjadikan Rekso Roemekso 
Djawi Hisworo berubah haluan menjadi anti Kolonialisme. Surat kabar ini muncul sebagai bentuk pengajaran bagi masyarakat Surakarta. Djawi Hisworo merupakan surat kabar yang tidak diterbitkan dibawah organisasi pergerakan, melainkan milik perorangan atau instansi non pergerakan.

Djawi Hisworo mendukung SI sampai pada tahun 1917. Dalam terbitannya, Djawi Hisworo banyak mengeluarkan artikel yang berisi kritikan terhadap orang Eropa. Selain itu, juga banyak menerbitkan tulisan yang berisi tentang anti kolonialisme, yaitu tentang banyaknya orang-orang eropa yang melanggar hukum. Djawi Hisworo mengusung Nasionalisme Jawa sesuai ideology Martodharsono yang menganut Kejawen. Dalam perkembangannya, Djawi Hisworo dibantu oleh Samanhoedi dan orang-orang Rekso Roemekso. la membantu dalam hal pembiayaan dan penerbitan. DjawiHisworo menjadi salah satu pilar yang mendukung panji-panji SI. Namun, juga menjadi media perseteruan antara Martodharsono dan Cokroaminoto.

Surat kabar Djawi Hisworo mengegerkan massa ketika menertbitkan salah satu atikelnya yang berisi tentang penistaan terhadap agama Islam. Pada Januari 1918 m uncul sebuah artikel yang berjudul Prtjakapan Antara Marto dan Djojo. Tulisan ini mengandung penghinaan terhadap nabi Muhammad. Artikel ini menuliskan sosok Nabi Muhammad yang sedang mabuk ketika menerima wahyu. Dari Allah. Pada awalnya tulisan ini tidak menimbulkan perdebatan bagi masyarakat Surakarta. Namun, kemudian memicu reaksi umat Islam

sebagai organ berbadan hukum. Selain itu, ia juga menjalankan kantor SI Surakarta di Purwosari, Laweyan, Surakarta pada saat hubungan Samanhoedi dengan Cokroaminoto mengalami perseteruan. Martodharsono terus bersama Samanhoedi ketika SI Surakarta mengalami penurunan pada tahun 1916 ketika pusat SI pindah di Surabaya dengan pergantian Cokroaminoto sebagai ketua. Selain itu, Martodharsono juga memiliki pemikiran yang berbeda dengan tokohtokoh SI seperti Cokroaminoto dan Agus Salim. Ia memiliki ideologi nasionalisme Jawa dengan kultur kebatinan yang sangat kuat, sesuai karakternya yang menganut kejawen. Zulyani Evi, Dianggap Menghina nabi, ia diburu Seluruh umat, (Geschieporia Magz), (https://gphoriablog.wordpress.com/2018/04/24/dianggap-menghina-nabi-iadiburuseluruh-umat). 
yang tidak terima dan merasa agamanya telah dilecehkan. Tak hanya di Surakarta, artikel ini kem udian diangkat menjadi isu nasional. ${ }^{20}$

Artikel tersebutmemberitakan:

"Ah seperti pegoeron (tempat beladjar ilmoe). Saja boekan goeroe, tjoemah bertjerita atau memberi nasehat, kebetoelan sekarang ada waktoenja. Maka baiklah sekarang sadja. Adapoen fatsal (selamatan) hoendjoek makanan itoe tidak perlu pakai nasi woedoek dengan ajam tjengoek brendel. SEBAB GOESTI KANDJENG NABI RASOEL ITOE MINOEM TJIOE A.V.H DAN MINOEM MADAT, KADANG KLE'LE'T DJOEGA SOEKA. Perloe apakah mentjari barang jang tidak ada. Maskipoen ada banjak nasi woedoek kalau tidak ada tjioe dan tjandoe tentoelah pajah sekali."(Djawi Hisworo, 11 Januari 1918). ${ }^{21}$

Sehari setelah artikel itu dimuat, pada awalnya Surakarta masih ayem tentrem, dan tidak ada gejolak dari masyarakat, demikian pula daerah-daerah yang lainnya. Pemberitaan yang dimuat Djawi Hiswara kalah ramai dengan pemberitaan tentang rencana Volksraad yang akan memilih anggota-anggota baru dikalangan bumiputera pada 17 Januari $1918 .^{22}$

Reaksi awal muncul pada tanggal 30 Januari 1918 di Surabaya. Cokroamimoto mempengaruhi masyarakat Surabaya dan memanfaatkannya dengan mengangkat nilai kebangsaan tanpa membeda-bedakan suku, yaitu Islam menjadi bagian terpenting dan menjadi ciri kebangsaan bumiputera. Pada tanggal 6 Februari di

${ }^{20}$ Benturan Ideologi antara Nasionalisme Jawa dan Pembaharuan Islam tejadi saat kasus penistaan agama ini muncul. Pada masa itu, kaum Nasionalisme Jawa secara umum tidak menerima Islam yang lebih reformis dan cenderung melihat Majapahit sebagai masa keemasan. Mereka menganggap islam diajarkan oleh kaum pembaharu dianggap sebagai impor asing dan tidak disukai. M.C, Ricklefs, Sejarah Indonesia Modern 1200-2004, (Jakarta : Serambi, 2005) HIm. 366-367

21 "Ah seperti perguruan (tempat belajar ilmu) saja. Saya bukan guru, Cuma bercerita atau memberi nasihat, kebetulan sekarang ada waktunya. Maka baiklah sekarang saja. Adapun pasal (selamatan) hunjuk makanan itu sendiri tidak perlu pakai nasi wuduk dengan ayam cenguk brendel. SEBAB GUSTI KANJENG NABI ROSUL ITU MINUM CIU AVH DAN MINUM MADAT, KADANG KLE'LET JUGA SUKA. Perlu apakah mencari barang yang tidak ada. Meskipun ada banyak nasi wuduk kalau tidak ada ciu dan candu tentulah payah sekali (Djawi Hisworo, 11 Januari 1918) Artawijaya, Jaringan Yahudi Internasional di Nusantara, (Jakarta : Pustaka AtKautsar, 2010), hal. 151-152

22 Pada saat itu pentolan-pentolan politik yang ada pada setiap organisasi di Hindia Belanda fokus pada isu tersebut dan pergi ke Batavia dimana tempat Dewan Rakyat berada. 
Surabaya didirikan komite Tentara Kandjeng Nabi Muhammad $(\text { TKNM })^{23}$ untuk mempertahankan kehormatan Islam, Nabi, dan Kaum Muslimin (Apriyata Dzikri Romadhon, t.t.). Pendirian TKNM kemudian mendapat protes dari penganut liran Kejawen. Orang-orang Jawa pun kemudian membentuk Komite Nasionalisme Jawa (Comitte Voorhet Javaanche Nationalisme). Organisasi ini didirikan untuk menandingi TKNM yang dianggap sebagai penghalang orang-orang Jawa dalam mengajarkan ajaran Kejawen. Mereka menganggap TKNM ditunggangi oleh kepentingan asing, yakni Arab, sehingga ada upaya untuk menghalangi untuk menghalangi bangsa Jawa untuk mengamalkan kepercayaan Jawa, dan menghalangi kepercayan lain diluar Islam (Apriyata Dzikri Romadhon, t.t.).

Aksi proses juga dilakukan oleh adik Cokroaminoto yang bernama Abikusno Cokrosujoso melalui surat kabar Oetoesan Hindia pada 30 Januari 1918 yang juga diterbitkan oleh Medan Muslimin pada awal Februari 1918 yang berjudul "Si Djahat Menghina Nabi SAW". la menuntut PakubuwonoX dan Pemerintah Hindia Belanda menghukum Martodharsono dan Djojokiro selaku penulis artikel tersebut atas apa yang telah dilakukannya. Abikusno menuliskan:

"Baginda, ketahoeilah didalam darah negeri baginda (Solo) ada terbit satoe soerat kabar yang memoeat perkataan-perkataan sangat kedji dan sangat menghina djoendjoengan Nabi dan menghina kita kaoem Islam semoea itoe. Betapakah fikiran baginda?

Patik mengetahoei, baginda, bahwa baginda seboetkan diri baginda: Abdurrachman Sajidin Panotogomo. Patik pertjajta dengan jakin, bahwa baginda akan mendapatkan alasan dan sebab-sebab, boeat memberi alasan dan kedjahatankedjahatan, jang menghina Nabi kita sekalian kaoem Islam itoe.

23 Tentara Kandjeng Nabi Muhammad didirikan di Surabaya dengan Cokroaminoto sebagai ketuanya. Sementara itu, Sosrokardono sebagai sekretaris, dan Syekh Ambarak bin Thalib (pemimpin Al Irsyad Surabaya) sebagai bendahara. Disaat berita ini menjadi isu nasional, banyak umat Islam yang bergabung dalam TKNM. Dalam rapat-rapat TKNM yang diselenggarakan untuk memproes Djawi Hisworo, selalu dihadiri oleh banyak orang. Seperti 5000 orang di Sumenep, 1000 orang di Bangkalan, dan 800 orang di Sampang. Baca hasil penelitian Juma, Kontinuitas dan Transformasi Penistaan Agama, Jurnal Lektur Keagamaan, Vol 16, No . 02, $2018372-394$, hal. 380 
Pergoenakanlah baginda ampoenja kekoeasaan!" (Oetoesan Hindia, Kamis , 30 Januari 1918)

Aksi-aksi protes yang dilakukan TKNM yang tidak terima atas perilaku orang-orang Kejawen yang menghina nabi, pada akhirnya ditanggapi oleh orang-orang Kejawen. Sebagai respon dari aksi-aksi TKNM kemudian Martodharsono menanggapinya dengan menjelaskan bahwa ia telah menambah catatan dibawahnya bahwa apa yang ditulis Djojokiro mengandung maksud lain dan tidak bermaksud menyalakan api kemarahan kaum muslimin. Martodharsono menambahkan catatan dalam artikel tersebut, "Orang lain yang tidak paham memang bisa tesinggung dengan isinya, sebab Nabi Muhammad terkesankan berhubungan dengan arak dan candu." Padahal tidak bermaksud menghina. Jika ditafsirkan secara harfiah dan jika orang mengenal baik sastra Jawa (Jawa-Islam : Keasingan dan Pertemuan", Tempo, 21 Janari 1978). Dalam catatan Martof Harsono menulis:

"Rembag mekaten regtosipun oten kenging dipun gelar hing serat kabar, hawit sam pun mesti damel sak serik hingkang boten di oengkap."(Pertjakapan selakoe ini seseoenggoehnya tidak boleh dihampar di soerat kabar, sebab soedah tentoe bikin koerang senang hati yang tidak mengerti). "Bahwa saja tidak sadja menegah pada djojokiro joega memaloemkan kaloe toelisan mana arti lain soepaja djangan ada yang menerima salah, sedangkan dimaksoednja, jang dikatakan rosul dalam perjtakapan itoe, bukan nabi saw. Kandjeng Nabi Muhammad rasoel Allah, tetapi rasoel (goevel) nya masing-masing, jadi siapa yang bertjakap ialah yang mempoenjainja. Demikianlah mananja jang saja kira tiap tiap orang abangan mesti mengert, asal sadja pernah bergoeroe tentang ilmu yang oemoemnja $d$ bidang ilmoe kematian..." 24

24 "Diskusi semacam itu sesungguhnya tidak layak digelar di surat kabar, sebab sudah pasti akan membuat orang tidak senang hati yang tidak mengerti ." (Percakapan selaku ini sesungguhnya tidak boleh diigelar di suratkabar, sebab sudah tentu bikin kurang senang hati yang tidak mengerti. "Bahwa saya tidak saja mencegah pada Djojokiro juga memaklumkan kalau tulisan ini memiliki makna lain supaya jangan ada menerima salah, sedangkan yang dimaksudnya, yang dikatakan rosul dalam percakapan itu, bukannabi SAW. Kanjeng Nabi Muhammad rosul Allah, tetapi rosul (guvel) nya masingmasing, jadi yang berbicara ialah yang mempunyainya. Demikianlah maknanya yag saya kira orang abangan mesti mengerti, asal saja pernah berguru tentang ilmu yang umumnya di bidang ilmu kematian..." Terj. Marthodarsono, Djawi Hiswara, 4 Februari 1918 
Martodharsono juga menyerang balik apa yang telah dilakukan oleh Abikusno Cokrosuyoso bahwa serangan terhadap Martodharsono hanyalah karena Kongres CSI di Yogyakarta dan pilihan president. la menganggap saat itu ia berada pada pihak yang bagus yaitu bersa,a Samanhoedi, Henk Sneevliet dan Marco. la juga mengkritik Cokroaminoto yang menggantikan Samanhoedi yang merupakan bapak SI. la menulis:

"Perkara koeno kata saja, ja'ni sebatas congres CSI di Djocja (Jogjakarta) dan pilihan President, wektoe mana saja m isih djadi Redacteurnja Sarootomo, moelai itoe dan selandjoetnja saja selaloe tinggal di fihak jang saja pandang bagoes lagi toeloes haloeanja seperti toean Semaoen, toean Marco, djuga toean Sneevliet dan toean Baars, walaoepoen Belanda, atjapkali saja bintjangkan dan saja poedji, tetapi sebaliknja saja djadi gagoe daripada saja misti memoedji Tjokroaminoto jang moedah poetoeskan djandjinja, antara toean Hadji Samanhoedi itoe, bapak SI itoe, pada hal djandjinja terkoentji dengan soempah, lebih teges saja tidak pernah memoedji akan dia, melingkan membilangkan sadja apa jang ada dengan sebenarnja. Itoe sebab complotnja amat membentji pada saja." 25

Pada kasus ini memang sudah terjadi perpecahan dalam Sarekat Islam. Banyak anggota Sarekat Islam yang menjadi anggota Komunis. Terdapat konflik kepentingan dalam tubuh SI. Bahkan Martodharsono juga menunjukkan mengenai keterpihakannya terhadap kelompok sayap kiri. Martodharsono menduga, serangan terhadap dirinya ini adalah karena kedekatannya dengan kelompok SI Semarang dan Djawi Hiswara. Disamping itu, dalam mengadapi kasus ini, SI Semarang tidak terlalu menanggapinya dan lebih fokus pada aksi mogok kerja.

${ }^{25}$ Perkara kono kata saja, yakni sebatas kongres CSI di Jogja (Jogjakarta) dan pilihan presiden, waktu mana saya masih jadi redakturnya Sarotomo, mulai itu dan selanjutnya saya selaly tinggal di pihak yang saya pandang bagus lagi tulus haluannya seperti tuan Semaun, tuan Maro, juga tuan Sneevliet dan tuan Baars, walaupun Belanda, acapkali saya bincangkan dan saya puji, tetapi sebaliknya saya jadi gagu daripada saya mesti memuji Cokroaminoto yang mudah putuskan janjinya, antara tuan Haji Samanhudi itu, bapa SI itu, pada hal janjinya terkunci dengan sumpah, lebih tegas saya tidak memuji akan dia melainkan membilangkan saja apa apa yang ada dengan sebenarnya. Itu sebab komplotannya amat membenci saya. Terj. Ibid. 


\section{Politisasi Cokroaminoto Terhadap Penistaan Agama Pada Surat Kabar Djawi Hisworo}

Kasus penistaan agama yang dilakukan oleh Martodharsono dan Djojokiro dalam surat kabar Djawi Hisworo kemudian dimanfaatkan oleh Cokroaminoto untuk kepentingan politiknya. Cokroaminoto memanfaatkan kasus ini untuk mengangkat namanya, sehingga dapat kembali memperkuat kedudukan politiknya baik dalam tubuh SI maupun di Hindia Belanda dengan mengatasnamakan perjuangan membela Islam dan kaum Muslimin. Pada saat itu kedudukan Cokroaminoto sebagai ketua CSI mengalami permasalahan dimana posisinya terganggu atas keberadaan Semaoen dan orang-orangnya. Selain itu Cokroaminoto juga tidak memiliki hubungan baik dengan masyarakat Kejawen. Keberadaan Semaoen dan orang-orangnya membuat Cokroaminoto tidak bisa mengontrol SI secara penuh. ${ }^{26}$ Selain perpecahan internal dalam tubuh $\mathrm{SI}$, antusiasme masyarakat terhadap SI juga berkurang. Hal ini kemudian menyebabkan kondisi keuangan SI menurun.

Cokroaminoto kemudian melakukan beberapa langkah politis yang akhirnya dapat mengangkat namanya dan menarik banyak pengikut. Kontroversi Djawi Hisworo kemudian di politisasi oleh Cokroaminoto dengan melakukan tiga hal. Pertama, menghimpun saudagar-saudagar santri dan Arab. Kedua, menghimpung uang, dan ketiga, menggerakkan Sarekat Islam yang terbengkalai dan dibawah pimpinannya dalam semangat bela Islam, lalu menyerang musuhmusuhnya dari Surakarta yaitu Samanhoedi dan Martodharsono. Selain itu, Cokroaminoto juga hendak menunjukkan bahwa selama ini pemerintah Hindia Belanda tidak mempedulikan Islam (Juma, 2018).

Hal pertama yang dilakukan oleh Cokroaminoto adalah menggaet umat Islam yang selama itu mendukungnya. la memiliki kedekatan dengan masyarakat Muslim modernis, seperti Al Irsyad dan

${ }^{26}$ Orang-orang SI merah banyak yang melakukan kritikan terhadap kebijakan Cokroaminoto yang bersikap terlalu kooperatif dengan Pemerintah Hindia Belanda. Kritikan-kritikan yang dilakukan oleh musuh-musuhnya yang berada dalam tubuh SI sudah muncul ketika dalam kedekatannya dengan Dr Rinkes. Kedekatannya dengan Dr Rinkes yang padasaat itu menjadi penasihat urusan pribumi menjadi suatu hal yang penting baginya dan bagi SI. Hal ini dilakukan Cokroaminoto untuk kemajuan SI dan untuk memantapkan dirinya di posisi central SI. 
Muhammadiyah. Pergerakannya dimulai pada akhir Januari 1918 dengan mengajak Hasan bin Semityang merupakan pimpinan Al Irsyad yang juga merupakan komisaris CSI dengan mengadakan reli di Surabaya guna membicarakan mengenai penghinaan yang dilakukan oleh Martodharsono dalam surat kabar Djawi Hisworo tersebut. Rapat ini kemudian dilanjutkan dengan pembentukan TKNM (Takashi siraisi,t.t.).

Cokroaminoto juga menjelaskan bahwa TKNM merupakan pembelaan atas nama Islam karena dalam prosesnya tidak menarik dari berbagai kalangan. Hal ini juga berarti bahwa TKNM merupakan suatu wadah untuk semua kalangan umat muslim. Hal ini berarti juga bahwa Cokroaminoto ingin menggaet seluruh elemen umat Islam baik dalam tubuh SI maupun diluar SI supaya lebih dapat memiliki banyak pengikut. Melalui TKNM Cokroaminoto terus menerus melakukan perlawanan dan juga menghimpun para saudagar arab dan muslim bumiputra (Apriyata Dzikri Romadhon, 2014)

Strategi Cokroaminoto dalam menjalankan pergerakan ini sangatlah halus. la dapat mengumpulkan ribuan orang yang kembali mendukung dirinya dan Sarekat Islam. Militansi yang terdapat pada kaum Islam modernis merupakan senjata tajam dalam membela kepentingan Islam, dan kepentingan Cokroaminoto. Langkah Cokroaminoto ini berjalan dengan baik. Pada 20 Maret 1918, Oetoesan Hindia memutuskan hasil pemufakatan internal $\mathrm{SI}$ mengenai pengangkatan ketua CSI, Cokroaminoto menjadi anggota Volksraad. Dari cabang SI yang sah, terdapat 28 yang menyetujui pengangkatan tersebut, sedangkan 26 cabang tidak menyetujui. 3 blangko tidak sah, dan 1 blangko kosong. Dengan keputusan tersebut kemudian Cokroaminoto dapat menjadi anggota Volksraad dengan tenang (Slamet Muljana, 2008). Sesaat setelah diperoleh pemufakatan dari segenap cabang SI se Jawa dan Madura mengenai hal tersebut, Cokroaminoto segera menulis surat kepada Gubernur Jenderal Hindia Belanda Johan Paul Graaf Van Limburg Stirum mengenai kesediaannya duduk dalam keanggotaan Volksraad (Suradi, 2008).

Muhammadiyah juga mendukung aksi-aksi yang dilakukan oleh Cokroaminoto. Meskipun di Yogyakarta tidak didirikan sub komite TKNM, namun Muhammadiyah menyatakan dukungan terhadap 
Cokroaminoto. Protes-protes dilakukan dalam surat kabar secara individu, terutama ditulis dalam surat kabar Islam Bergerak. Muhammadiyah juga melakukan protes kepada keraton untuk mengambil tindakan atas perbuatan yang dilakukan oleh Martodharsono tersebut dan mengajak umat islam untuk membela agama Islam (Apriyata Dzikri Romadhon, 2014). Selain itu KH Ahmad Dahlan juga mem bantah pernyataan bahwa ia memberikan dukungan kepada Martodharsono. la juga mengaku bahwa belum pernah melakukan musyawarah dengan Djojokiro. Musyawarah yang dilakukan Muhammadiyah pada 22 Februari 1918 membahas mengenai permohonan hukuman kepada pemerintah atas kasus penistaan tersebut. Kh Ahmad dahlan juga menegaskan bahwa dirinya tidak berubah pikiran dan akan tetap membela agama Islam (Oetoesan Hindia, 27 Februari 1918).

Tingginya antusias masyarakat muslim dalam membela Islam mampu memberikan tekanan kepada pemerintah Hindia Belanda. Didalam Volksraad, bahkan Cokroaminoto berani menyampaikan kepada pemerintah bahwa harus menghukum Martodharsono dan Djojokiro. Hal ini menjadi perhatian bagi pemerintah, bahwa muslim bumiputera tidak bisa dianggap sepele. Meskipun demikian, Cokroaminoto belum memiliki tujuan dan langkah-langkah kemerdekaan. Fokus utama pergerakan Cokroaminoto adalah mendapatkan otonomi dan pemerintahan sendiri (Selfgoverment). Pendapat Cokroaminoto ini dijelskan ketika menjawab Darmakoesoemo wakil Insulinde pada perdebatan dalam sebuah surat kabar:

"Apakah artinya suatu negeri Hindia yang memerinth diri sendin tetapi tak mampu mempertahankan diri dan menggempur musuh ? Lebih banyaklah hak-hak harusnya lebih seiring dengan banyaknya kewajiban. Kewajiban dan hak harusnya lebih sama banyaknya. Ini merupakan tuntutan yang masuk akal. Kita memang harus punya kemerdekaan, tetapi juga harus mentaati hukum yang sehat. Ketertiban dan kemerdekaan itu sama dan sebangun." (Oetoesan Hindia, 27 Februari 1918).

Cokroaminoto kemudian memimpin vergadering TKNM di gedung Al-Jamiah Al-Khairiyah Al-Arabiah di Ketapang Surabaya pada 8-9 Mei 1918. Cokroam inoto menyambut langsung tamu pada alim ulama yang merasa gelisah atas penghinaan oleh Martodharsono tersebut. Para 
alim ulama yang hadir diantaranya adalah Sajid Mohammad SHaleh Chawasi, Sosrosoedewo, Syeikh Roebaja bin Thalib, Hasan Ali Soerati, Haji Hisamzaijni, Haji Asnawi, Kyai Adnan, Kyai Manshur, Syeikh Alwin bin Husein Syihab, Haji Hasan Gipo, Hosein bin Muhammad bin Usman, Syeikh Muhammad bin Salim Baradja, Haji Noorhasan. Pada vergadering tersebut kurang lebih dihadiri sebanyak 1000 umat muslim baik dari kalangan ulama bangsa Arab maupun Jawa. Vergadering ini kemudian menentukan mosi yang akan dikirim kepada Gubernur Jendral, Sri Susuhunan, dan Resident Surakarta tentang penistaan agama Djawi Hisworo (Adhytiawan Soeharto, 2018).

Dengan mengkanalisasi sentiment massa melalui semangat membela Islam, Cokroaminoto berhasil mengumpulkan dana yang banyak. Seruan TKNM yang begitu militan begitu berhasil. Keikutsertaan saudagarsaudagar muslim menjadi keuntungan tersendiri dalam meningkatkan keuangan dalam SI. Selain itu, TKNM berhasil membangkitkan kembali kepercayaan masyarakat muslim terhadap SI.Banyaknya dukungan dana dari pengikutnya merupakan suatu keuntungan besar bagi Cokroaminoto. Sebelumnya, banyak sekali cabang-cabang SI dibawah pimpinannya yang mengalami permasalahan keuangan. Dengan adanya dukungan dana yang banyak, Cokroaminoto dapat dengan lebih mudah dalam melakukan aksi politiknya. Vergadeering-vergadering yang dilakukan oleh TKNM berhasil menjadi sumber pendapatan dana. Vergadering yang dilakukan pada 6 Februari 1918 berhasil mengumpulkan dana lebih dari 3.000 gulden. Ditambah lagi, reli protes serentak yang dilakukan pada 24 Februari di 42 tempat diseluruh Jawa dan sebagian Sumatra dihadiri lebih dari 150.000 orang dan berhasil mengumpulkan dana lebih dari 10.000 gulden. Banyak SI lokal yang sebelumnya terbengkalai tetapi kemudian berhasil dibangkitkan dibawah pimpinan sub komite TKNM (Takashi Siraisi, t.t.).

Selain menggaet masyarakat muslim dan menghimpun dana, Cokroaminoto juga melakukan suatu kebijakan dalam tubuh SI akibat adanya pertentangan yang sering terjadi dengan golongan SI Merah. Untuk mengatasi hal tersebut, akhirnya diadakan sistem disiplin partai, dimana anggota SI tidak boleh memiliki keanggotaan rangkap dengan organisasi lain. Pada kongres SI ke-5 pada 6 oktober 1921 di Surabaya. 
Agoes Salim dan Abdul Moeis mengusulkan agar pemimpin pusat CSI menerapkan disiplin partai, anggota SI dilarang merangkap keanggotaan di organisasilain. Disiplin partai ini berarti pemurnian alias membersihkan SI dari pengaruh Kom unisme. Semaoen, Darsono dan kawan-kawannya tidak mau keluar dari keanggotaan Perserikatan Komunis Hindia. Pilihan tersebut pada akhirnya membuat mereka keluar dari keanggotaan Sarekat Islam dibawah pimpinan Cokroaminoto (Takashi Siraisi, t.t.).

\section{KESIMPULAN}

Konfigurasi politik didalam tubuh Sarekat Islam menyebabkan terjadinya konflik internal dalam tubuh Sarekat Islam. Seperti hal nya perang kepentingan antara Gunawan-Samanhoedi dengan Cokroaminoto. Hal ini menyebabkan antusiasme masyarakat terhadap SI merunun. Perbedaan pandangan pada tubuh SI juga menjadi kendala bagi Cokroaminoto untuk melakukan aktivitas politiknya sebagai ketua CSI, yaitu ketika SI terpecah menjadi SI merah dan SI putih. Pada saat itu SI Semarang yang dipimpin oleh Semaun terpengaruh oleh Komunisme melakukan kritikan-kritikan dan aksi-aksi yang mengganggu supremasi Cokroaminoto. Untuk memperkuat kembali kedudukannya pada akhirnya Cokroaminoto melakukan politisasi terhadap sebuah artikel yang berisi sebuah penistaan agama yang dimuat dalam Surat Kabar Djawi Hisworo. Polemik penistaan ini berhasil dimanfaatkan baik oleh Cokroaminoto. la berhasil memobilisasi massa yang terdiri dari masyarakat muslim untuk menuntuthukuman bagi Martodharsono dan Djojokiro selaku redaktur dan penulis artikel tersebut upayasy diberikan hukuman dengan semangat bela agama Islam dan kaum Muslimin. Cokroaminoto juga berhasil merekrut saudagar-saudagar muslim dan menggalang dana yang begitu banyak. Selain itu Cokroaminoto juga mendirikan Tentara Kandjeng Nabi Muhammad yang menjadi sebuah wadah pergerakan tersebut.

\section{DAFTAR PUSTAKA}

Djawi Hiswara, 4 Februari 1918

Djawi Hiswara, Januari 1918. 
Oetoesan Hindia, 30 Januari 1918

Oetoesan Hindia, 27 Februari 1918.

Oetoesan Hindia, 16 Maret 1918

Cokroaminoto, Islam dan Sosialisme, Bandung : Sega Arsy 2010

Siraishi Takashi, Zaman bergerak: Radikalisme Rayat di Jawa 1912-

1926, Jakarta : Putaka Utama Grafiti

Artawijaya, Jaringan Yahudi Internasional di Nusantara, Jakarta : Pustaka Al-Kautsar, 2010.

K Suntana, Septiawan 2006, Jurnalisme Kontemporer, Yogyakarta :Yayasan Obor

Tim Museum Kebangkitan Nasional, Djoko Marihandono, Harto Juwono, Yudha B Tangkilisan, HOS Cokroaminoto Penyemai Pergerakan Kebangsaan dan Kemerdekaan, Museum Kebangkitan Nasional Kementrian Pendidikan dan Kebudayaan

A.K Pringgodigdo, Sejarah Pergerakan Rakyat Indonesia, Jakarta : Dian Rakyat 1980

Amelz, HOS Cokroaminoto Hidup dan Perjuangan, Jakarta : Bulan Bintang

Safrizal Rambee, Sarekat Islam dan Pelopor Bangkitnya Nasionalisme Indonesia 1905-1942, Jakarta: Yayasan Kebangkitan Insan Cendekia,2008

Yasmis, Sarekat dan Pergerakan Nasional Indonesia, Jurnal Sejarah Lontar Vol 6, 1 Januari-Juni 2009

Juma, Kontinuitas dan Transformasi Penistaan Agama, IAIN Surakarta: Jurnal Lektur Keagamaan, Vol 16, No . 02, 2018 372-394.

Subarkah, Muhammad, Pemberontakan PKI Madiun: Akar Konflik Islam VS Komunis, (Republika: Khazanah) Rabu 17 Juni 2020 16:01 WIB

Samudro, Dewanto, Dari Pers Hindia Belanda Hingga Pers Pergerakan Nasional, Antarnews.com : Minggu 10 Februari 2019, 09:19 WIB Agung DH, Saat Penistaan Agama Lahirkan Tentara Kanjeng Nabi Muhammad, Tirto Id: Politik

Raditya, Iswara N, Tuduhan Korupsi dan Tamatnya Raden Goenawan dalam Sarekat Islam, Tirto Id : Humaniora.

SI Hijau dan Merah : Antar Cokroaminoto dan Semaun, Saturday : 29 Septem ber 2018, 05:01 
Redaksi, Jawa Islam : Keasingan dan Pertemuan, Tempo : 21 Januari 1978

Adhytiawan Soeharto, Cokroaminoto dan Tentara Kanjeng Nabi Muhammad, Warta Muslimin : 18 Januari 2018 